КРИСТАЛЛОГРАФИЧЕСКИЙ МЕТОД МАТЕМАТИЧЕСКОГО МОДЕЛИРОВАНИЯ ОБЪЕКТА ТИПА «ПЕРСПЕКТИВНАЯ ПОДВИЖНАЯ СИСТЕМА РАДИОСВЯЗИ ВОЕННОГО НАЗНАЧЕНИЯ ОПЕРАЦИОННЫЙ РАЙОН - СИСТЕМА РАДИОРАЗВЕДКИ ПРОТИВНИКА»

А.П. Волобуев, А.В. Федин

В статье предложен метод математического моделирования объекта типа «перспективная подвижная система радиосвязи военного назначения - операчионный район - система радиоразведки противника», с помощью которого решается задача создания математической модели данного объекта для исследования уровня ее радиомаскировки и которая может быть взята за основу при разработке алгоритмического обеспечения децентрализованной системы управления системой радиосвязи, в частности управления уровнем радиомаскировки.

Ключевые слова: перспективная подвижная система радиосвязи, система радиоразведки противника, радиомаскировка.

\title{
CRYSTALLOGRAPHIC METHOD OF MATHEMATICAL MODELING OF OBJECT TYPE "PERSPECTIVE MOBILE RADIO SYSTEM OF MILITARY DESIGNATION - OPERATIONAL AREA - SYSTEM OF ENEMY RADIO RECONNAISSANCE"
}

\author{
A. Volobuiev, O. Fedin
}

The method of mathematical modeling of object type "perspective mobile radio system of military - designation - operational area system - enemy radio reconnaissance", which solves the problem of creating a mathematical model of this object to research level radio masking and which can be used as a basis for the development of algorithmic support of decentralized management system communication system, in particular the management of radio masking level has been presented in the article.

Key words: advanced mobile communication system, the enemy signal monitoring system, radio masking.

\section{УДК 623.438 .2}

О.М. Калінін, В.В. Костюк, Р.Г. Будяну

Академія сухопутних військ імені гетьмана Петра Сагайдачного, Львів

\section{ВИЗНАЧЕННЯ ПОКАЗНИКІВ ОСНОВНИХ ГРУП ОПЕРАТИВНО-ТАКТИЧНИХ ВИМОГ ДЛЯ СТВОРЕННЯ КОЛІСНИХ БОЙОВИХ БРОНЬОВАНИХ МАШИН}

Розглянуто питання щзодо визначення показників основних груп оперативно-тактичних вимог для створення колісних бойових броньованих машин. Наведений спектр використання бойових броньованих машин у воєнних конфліктах, операџіях з підтримання миру та безпеки, визначені тип колісних бойових броньованих машин відповідно до їхнього призначення та оперативно-тактичних вимог.

Ключові слова: бойова броньована машина, бойове застосування, оперативно-тактичні вимоги.

\section{Вступ}

Актуальність. Зміни у воєнно-політичній обстановці у світі, наявність загроз локальних збройних конфліктів та війн зумовлюють необхідність підвищення ефективності застосування озброєння і військової техніки (ОВТ) в Збройних Силах (3С) України.

Серед характерних рис сучасної збройної боротьби можна виділити високоманеврені (мобільні) дії військ (сил) на розрізнених напрямках із широким застосуванням сил швидкого реагування, аеромобільних військ, десантів і військ спеціального призначення.

В умовах антитерористичних (контртерористичних) операцій, партизанської та інших форм так званої «малої» війни (а саме вони отримують сьогодні в світі найбільше розповсюдження), а також «винайденою» нині Росією «гібридної війни», яку вона веде проти України, особливу увагу заслуговує питання ефективного технічного забезпечення підрозділів у зоні бойових дій.

Евакуація поранених; підвезення боєприпасів, медикаментів, продовольства, пально-мастильних матеріалів до блокпостів і вогневих позицій військ; перевезення особового складу механізованих підрозділів і вирішення інших завдань логістики в зоні бойових дій повинно здійснюватися бойовими машинами, які мають достатню захищеність, вогневу потужність і протимінну стійкість.

Спроби використовувати БТР і БМП для захисту від атак терористів під час пересування колон, до складу 
яких входять автомобілі багатоцільового призначення (АБП), виявились недостатньо ефективними. У результаті таких обставин практично всі передові армії світу приступили до оснащення своїх військ спеціальними захищеними автомобілями типу MRAP (англ. Mine Resistant Ambush Protected - захищені від підриву i атак із засідок).

Тому використання для таких цілей бойових броньованих машин (ББМ), які мають достатню захищеність, вогневу потужність і протимінну стійкість, $є$ однією з важливих проблем для ЗС України, які потрібно вирішувати найближчим часом. Це сприятиме ЗС України успішно виконувати свої функції щодо оборони держави у збройних конфліктах сучасності.

Аналіз попередніх публікацій. Досвід використання АБП під час ведення останніх бойових дій в Іраку, Афганістані, Чечні, зокрема, Антитерористична операція на Сході України, свідчать про необхідність підвищення їхньої захищеності.

Проведений аналіз $[1,2]$ свідчить, що для захисту АБП застосовується як повне, так і локальне бронювання. На ранніх етапах війни в Іраку основним критерієм щодо захищеності машин була їх невисока вартість. Зокрема, використовувалися підручні засоби захисту: стальні пластини, бронежилети, броньоване скло на дверях машин, мішки з піском для захисту від куль і вибухової хвилі. Однак такі заходи виявилися не ефективними. Установка навіть базового захисту на легковий автомобіль приводила до значного зниження його вантажності. Навіть, якщо вантажність не була основними критерієм, то виникали інші проблеми: напруження металу, навантаження на мости, шини, рульове керування. Таке бронювання значно знижує ресурс роботи машини, зумовлює часткове збільшення шляхової витрати палива і зменшення швидкості руху, але підвищує живучість зразка та екіпажу.

Забезпечити повну захищеність АБП в сучасних умовах розвитку засобів ураження неможливо навіть при одночасному застосуванні як змінних навісних захисних комплектів, так і конструктивно вбудованих.

За оцінкою експертів у галузі створення ББМ, найдинамічніше розвивається створення машин 3 конструктивно вбудованими броньованими елементами [3-7]. Перевага надається колісному шасі, яке характеризується високою рухомістю, великим запасом ходу, меншою собівартістю виробництва i невеликими витратами на утримання, технічне обслуговування та ремонт.

Постановка проблеми. Однією 3 головних вимог до ведення групової тактики бойових дій $є$ формування сучасних військових «структур» (мобільних сил швидкого реагування), в яких окремо взята одиниця БМП повинна мати високий ступінь бойової готовності, оперативну мобільність та здатність швидкого переміщення.
Потреби ЗС України у нових зразках ББМ з високими тактико-технічними характеристиками повинні бути визначені ще на етапі проектно-технологічних робіт шляхом обгрунтування раціональних тактикотехнічних характеристик і оперативно-тактичних вимог.

Враховуючи особливості їхнього застосування в сучасних збройних конфліктах, ББМ повинна бути уніфікована на базовому шасі єдиної колісної платформи.

Формування мети статті. На даний час в Україні є вітчизняні зразки колісних ББМ: “Козак” “Дозор-Б” і “Кугуар”. Ці ББМ мають неоднакове базове шасі, оскільки випускаються різними заводамивиробниками. За результатами попередньо виконаного порівняльного аналізу рівня технічної досконалості колісних ББМ встановлено, що вони несуттєво поступаються у своєму класі найкращим однотипним закордонним зразкам (HMMWV M1151A1wB1 (США), LMV (Італія), “Тигр” (Росія), Auferland A4 AVL (Франція)). У свою чергу жоден із розглянутих зразків за рівнем технічної досконалості не відповідає оцінкам “високий” і “відмінний». Це засвідчує про перспективи подальшого вдосконалення.

Метою статті $є$ визначення показників основних груп оперативно-тактичних вимог для створення уніфікованих колісних зразків ББМ з однаковими базовими шасі.

\section{Виклад основного матеріалу}

Серед завдань, які покладаються на СВ ЗС України, колісні ББМ можуть у мирний час використовуватись для проведення:

- антитерористичних, стабілізаційних, спеціальних та міжнародних операціях з підтримання миру i безпеки;

- посилення охорони державного кордону.

В особливий період вони можуть бути задіяні в:

- оборонних і наступальних операціях;

- ліквідації (локалізації, нейтралізації) збройного конфлікту;

- прикритті ділянки державного кордону у визначених операційних районах;

- ізоляції району конфлікту;

- охороні об’єктів і комунікацій;

- ураженні угруповань сил противника, які вторглися;

- протидії диверсійно-розвідувальним силам, незаконним збройним формуванням і терористичним групам;

- технічному забезпеченні підрозділів і частин 3С України та інших військових формувань.

Аналіз особливостей використання колісних ББМ у сучасних воєнних конфліктах, операціях 3 підтримання миру та безпеки показує, що спектр їхнього бойового застосування є дуже різноманітним (рис. 1). 


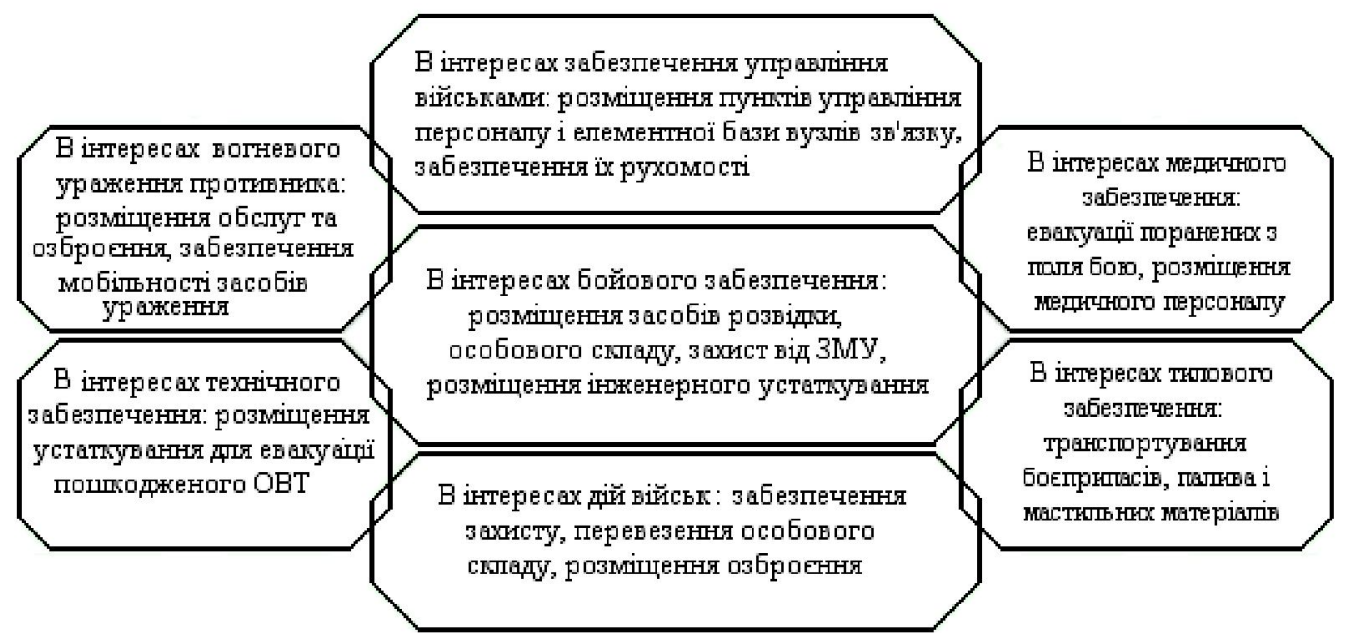

Puc. 1. Спектр бойового застосування колісних бойових броньованих машин

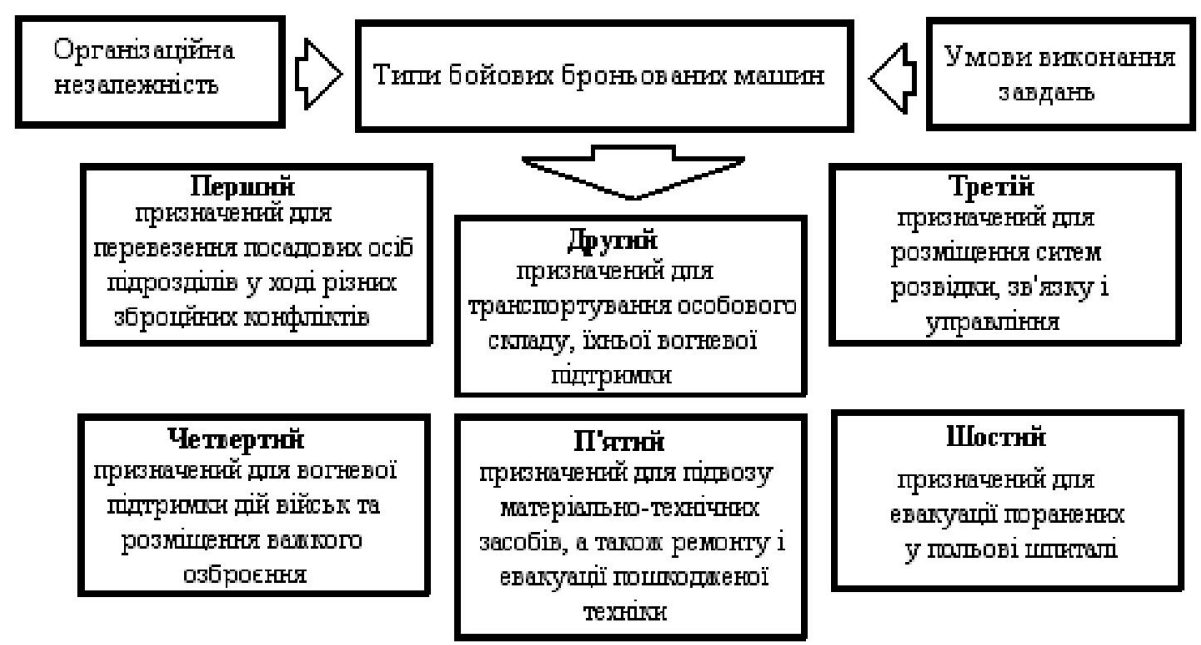

Puc. 2. Типи перспективних колісних бойових броньованих машин

Принцип створення перспективних колісних ББМ передбачає уніфікованість і модульне виконання його основних складових частин, обгрунтування оперативно-тактичних $\mathrm{i}$ тактико-технічних вимог. Відповідно до завдань, які вирішують колісні ББМ в сучасних бойових діях $з$ врахуванням спектра бойового застосування, пропонується розділити ББМ на п’ять груп (рис. 3).

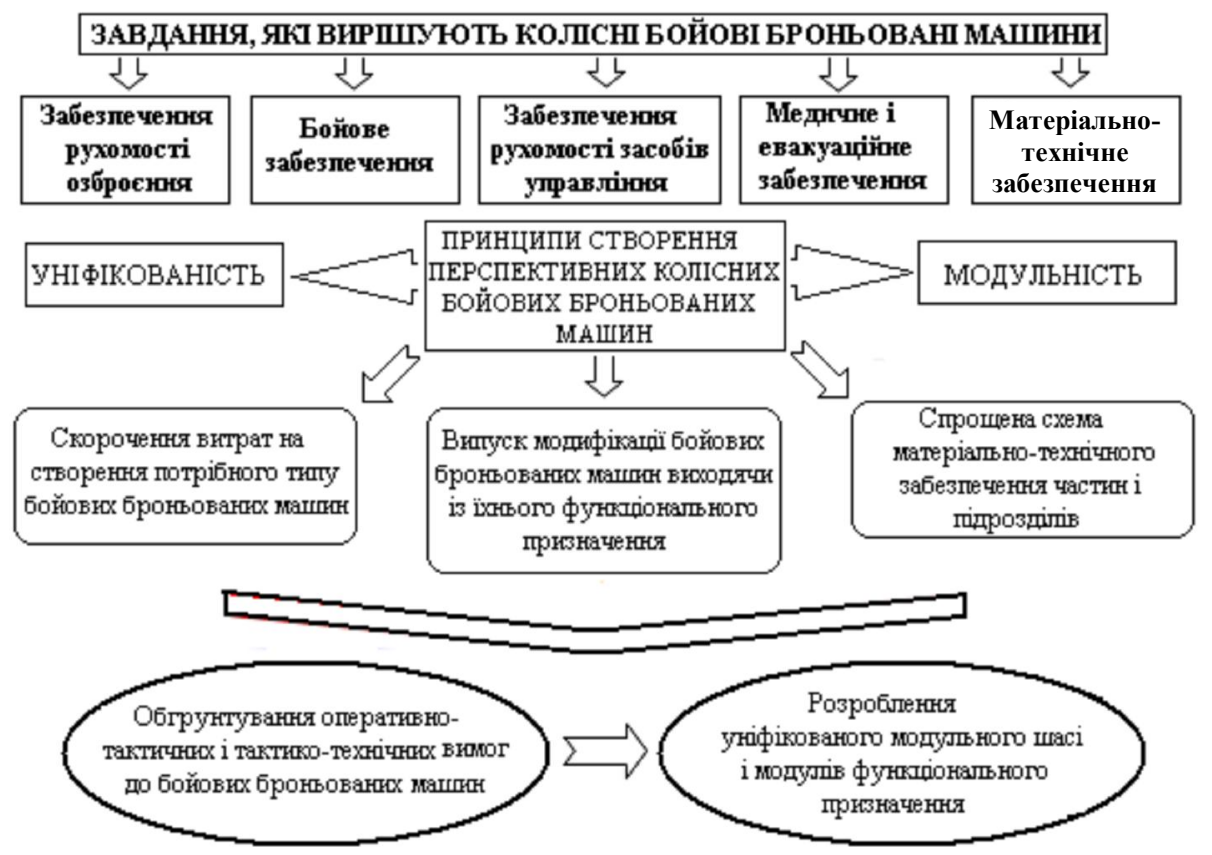

Рис. 3. Принципи створення перспективних колісних бойових броньованих машин 
У цілому модульний принцип побудови броньованої техніки та озброєння передбачає базову та функціональну частини зразка. До базової частини входять базовий модуль, модуль управління і модуль захисту. Базовий модуль ББМ є автономною броньовою конструкцією на колісному шасі. Функціональна частина складається із модулів озброєння, розвідки, навігації та зв'язку, які виконуються у вигляді швидкознімних конструкцій. У разі необхідності модуль за короткий час може бути замінений іншим (аналогічним або іншого призначення). Цей принцип дозволяе скоротити витрати на створення необхідного типу колісних ББМ і суттєво спростити систему матеріальнотехнічного забезпечення частин і підрозділів.

Принципи створення колісних ББМ формуються на певних визначених та обгрунтованих оперативнотактичних вимогах до заданого типу озброєння та військової техніки.

Оперативно-тактичні вимоги - це вимоги, що висуваються до бойових можливостей і ефективності застосування зразка (комплексу, системи) озброєння та військової техніки для виконання поставлених бойових задач у складі угруповання військ (сил).

Сучасні вимоги щодо захищеності колісної ББМ передбачають посилення бронювання корпуса, протимінний захист нижньої частини шасі від дії піхотних, протитанкових і саморобних вибухових пристроїв (не нижче 3-4 рівня захищеності відповідно до стандартизації HATOSTANAG 4569):

- захист від ураження стрілецькою зброєю калібром до $12,7(14,5)$ мм по всьому периметру, включаючи захист двигуна від 7,62-мм бронебійних куль, можливості дооснащення зразків додатковими як пасивними, так і активними засобами захисту;

- протимінний захист повинен забезпечувати стійкість від підриву під колесом фугасу потужністю не менше 8-10 кг у тротиловому еквіваленті;

- можливість оснащення комплексом засобів зниження помітності в оптичному, тепловому і радіолокаційному діапазоні.

Ефективність бойового застосування залежить від вогневої потужності озброєння зразка:

- одномісного або двомісного уніфікованого бойового модуля 3 дистанційним керуванням, які оснащені комплексом озброєння у складі: 30-мм автоматичної гармати; 7,62-мм спареного кулемета; протитанкового ракетного комплексу і автоматичного гранатомета або комплексу 3 двох автоматичних гармат меншого калібру;

- установки двоплощинної стабілізованої дистанційно керованої платформи комплексу озброєння;

- системи виявлення, розпізнавання цілей та наведення зброї, яка забезпечує пошук та виявлення живої сили і техніки противника у будь-яку пору доби та погодних умов на відстані не менше ніж 3 км.
Вимоги щодо маневреності і надійності колісних ББМ:

- потужність силової установки, трансмісії, ходової частини повинні забезпечувати прохідність колісної ББМ у різних дорожніх і кліматичних умовах;

- максимальна швидкість руху машини повинна становити не менше ніж 80-100 км/год, а середня швидкість по пересіченій місцевості (грунтових дорогах) повинна бути не менше ніж 40-45 км/год;

- ходова частина і трансмісія повинні комплектуватися автоматичною коробкою передач, незалежною торсіонною підвіскою і куленепробивними шинами 3 централізованою системою регулювання тиску повітря;

- збільшення ресурсу напрацювання зразка до капітального ремонту не менше ніж 260 тис. км, збільшення інтервалу періодичності технічного обслуговування (ТО): ТО-1 - через 15 тис. км пробігу, час на заміну будь-якого несправного агрегату в польових умовах повинен не перевищувати 1-4 год;

- скорочення нормативного часу та трудомісткості технічних операцій під час приведення у готовність до бойового використання;

- всі типи колісних ББМ повинні бути пристосовані до перевезення автомобільним, залізничним i водним транспортом, а легкі бойові броньовані машини - транспортною авіацією 3 можливістю їхнього десантування.

Крім розглянутих основних оперативно-тактичних вимог, колісні ББМ повинні також відповідати вимогам щодо умов застосування в операціях (бойових діях), живучості і стійкості до зовнішніх впливів та природних факторів, комфорту і ергономіки тощо.

\section{Висновки}

Основним фактором, що визначає характер сучасної збройної боротьби, є наявність нових міжвидових мобільних угруповань.

Застосування як повного, так і локального бронювання АБП значно знижує ресурс роботи машини, що спонукає до створення спеціальних броньованих автомобілів типу MRAP.

Досвід воєнних конфліктів та Антитерористична операція на Сході України підтверджують, що колісні бойові броньовані машини відіграють важливу роль у вирішенні широкого спектра бойових завдань.

Формування показників основних груп оперативно-тактичних вимог повинно визначатися з урахуванням бойових можливостей підрозділів сухопутних військ, під час виконання ними завдань за призначенням, 3 урахуванням прогнозованих умов бойової обстановки.

Визначення показників основних груп оперативнотактичних вимог стосовно перспективних колісних ББМ повинно йти шляхом стандартизації, передбачати уніфікованість і модульне виконання його основних складових частин, автоматизації процесів управління 
вогнем і рухом, підвищення захищеності, живучості, командної керованості, автономності, поліпшення ергономіки тощо.

\section{Список літератури}

1. Боевое применение вооружений и военной техники 6 горно-пустынной местности Афганистана. - М.: Воениздат, 1990. $-232 c$.

2. Костюк В.В. Підвищення рівня захищеності автомобілів багаточільового призначення локальним бронюванням / В.В. Костюк, П.О. Русіло, В.П. Белена // Військово-технічний збірник. - № 2(5). - Львів: АСВ, 2011. - С. 17-22.

3. Василенко О.В. Основні світові тендениії розвитку озброєння та військової техніки для ведення війн у майбутньому / О.В. Василенко // Наука і оборона. - 2009. - № 4. C. $18-23$.

4. Изюмов Д. Некоторые бронетранспортеры и бронеавтомобили зарубежных стран / Д. Изюмов // Зарубежное военное обозрение. - 2011. - № 3. - С. 41-43.
5. Нестеркин В., Шабаков А. Разработка в США бронеавтомобилей по программе MRAP-ATV / B. Нестеркин, А. Шабаков // Зарубежное военное обозрение. 2009. - № 6. C. 39-40.

6. Кузнецов Ю. Основные направления развития боевых колесных машин зарубежных стран / Ю. Кузнеиов // Зарубежное военное обозрение. 2013. - № 4. - C. 46-51.

7. [Электронный ресурс] - Режим доступу: http://topwar.ru/64684-tayfunenok-nabiraetsya-silenok.html.

8. [Электронныи ресурс] - Режим доступу: http://topwar.ru/67364-bronevik-kraz-spartan-ozhidaniya-iproblemy.html.

Рецензент: к.т.н., доц. В.М. Зіркевич, Академія сухопутних військ імені гетьмана Петра Сагайдачного, м. Львів.

\title{
ОПРЕДЕЛЕНИЕ ПОКАЗАТЕЛЕЙ ОСНОВНЫХ ГРУПП ОПЕРАТИВНО ТАКТИЧЕСКИХ ТРЕБОВАНИЙ ДЛЯ СОЗДАНИЯ КОЛЕСНЫХ БОЕВЫХ БРОНИРОВАННЫХ МАШИН
}

А.М. Калинин, В.В. Костюк, Р.Г. Будяну

Рассмотрен вопрос относительно определения показателей основных групп оперативно-тактических требований для создания колесных боевых бронированных машин. Приведен спектр использования боевых бронированных мамин в военных конфликтах, операциях по поддержсанию мира и безопасности, определен тип колесных боевых бронированных машин в соответствии с их назначением и оперативно-тактическими требованиями.

Ключевые слова: боевая бронированная машина, боевое использование, оперативно-тактические требования.

\section{DETERMINATION OF INDEXES OF BASIC GROUPS IS OPERATIVE TACTICAL REQUIREMENTS FOR CREATION OF THE WHEELED FIGHTING RESERVED MACHINES}

\author{
A. Kalinin, V. Kostyuk, R. Budyanu
}

A question is considered in relation to determination of indexes of basic groups operatively tactical requirements for creation of the wheeled fighting reserved machines. The spectrum of the use of the fighting reserved machines is resulted in soldiery conflicts, operations on maintenance of the world and safety, certainly type of the wheeled fighting reserved machines in accordance with their setting and operatively tactical requirements.

Key words: fighting reserved machine, battle application, operatively tactical requirements. 